\title{
Differences in young tennis players' agility depending on their playing level
}

\author{
Bernardino J. Sánchez (ESP), Guillermo F. López (ESP) and Ainara Pagán (ESP)
}

ITF Coaching and Sport Science Review 2016; 69 (24): 19 - 21

\section{ABSTRACT}

This research aims to evaluate young tennis players' agility and to analyze the differences depending on their playing level. 24 male tennis players, aged between 8 and 10 years old were involved in this research and completed three different agility tests (the $5 \times 10 \mathrm{~m}$ test, the spider test and the hexagon test). The findings revealed that more advanced players reached significantly higher scores in each agility test.

\author{
Key words: Physical \\ conditioning, agility, playing \\ level. \\ Received: 18 March 2016 \\ Accepted: 16 July 2016 \\ Corresponding author: \\ Bernardino J. Sánchez \\ Email: bjavier.sanchez@um.es
}

\section{INTRODUCTION}

The speed of tennis strokes has increased, particularly over the last few years, so, players have to move quickly in different directions to be able to reach the ball and to hit it in the best possible conditions (Domínguez, 2011; Sánchez-Alcaraz, 2013). Thus, agility is a very important component in those sports that demand a direction change (Jones, Bampouras, \& Marrín, 2009), defined as "a rapid movement of the whole body changing direction as a response to a stimulus" (Sheppard, \& Young, 2006). Different findings from different research show that $60-80 \%$ of the motion/ movement during a tennis match is lateral, between $10-30 \%$ is linear and forward, and between $8-10 \%$ is linear and backwards (Pieper, Exler \& Weber, 2007). Besides, tennis players change direction an average of 4 times per point (Roetert, Ellenbecker \& Chu, 2003), but it is possible to change from just one movement to more than 15 changes of direction during a point (Kovacs, 2009).

So, initial acceleration and deceleration or stopping phase, and the capacity to make multi-directional explosive movements will be vital components for tennis players, and will determine their performance (Kovacs, 2007; Sánchez-Alcaraz, 2015).

Therefore, this research tries to know the values of young tennis players' agility and to analyse the differences, depending on their playing level.

\section{METHOD}

Sample

24 male tennis players aged between 8 and10 years, were supported by their national tennis federation (average age $=8.97 \pm .83$ years $/$ weekly training $=6$ hours) and 13 were not (average age $=9.17 \pm .68$ years $/$ weekly training $=3$ hours).

\section{Instruments}

$\mathbf{5 x 1 0}$ test: For this test, the player will stand behind the starting line, in a high starting position, and towards a line which will be 5 metres away. Given the signal, the player will have to run as fast as possible towards the next line, he has to step on it with one foot. They will immediately change direction to go back to the starting line, which they will have to step on. They will have to do this 5 times, completing a total of $50 \mathrm{mts}$. (Galiano, 1992). The stopwatch will stop when the player crosses the starting line and will register the time that they took for the test.

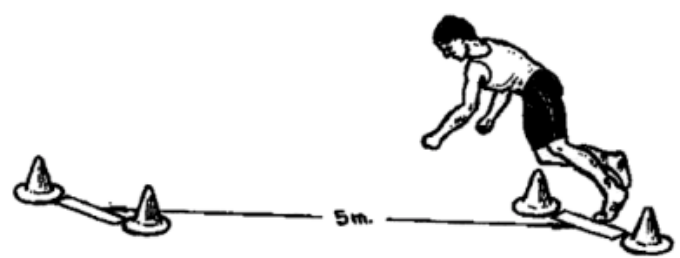

Image 1: $5 \times 10$ test (Martínez, 2008).

Hexagon test: For this test, the player will be at the centre of a $60 \mathrm{~cm}$ side hexagon. Given the signal, they will jump forward over the line and return to the centre of the hexagon. Looking in the same direction, they will repeat the action on each side of the hexagon clockwise. The stopwatch will stop when they have finished three complete turns, and their feet are at the centre of the hexagon again. The time that will be registered, will be the better of their two attempts.

Image 2: Hexagon test (Roetert \& Ellenbecker, 2008).

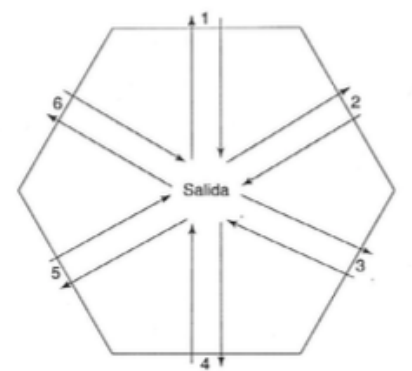

Image 2: Hexagon test (Roetert \& Ellenbecker, 2008).

Spider test: Having positioned the tennis balls in the corners and centre of the longest side of an $8.23 \times 5.49 \mathrm{~m}$ rectangle, the player will start from the centre of one of the sides, and will take each ball returning to the starting point "J" and will leave them as the next image indicates. When all balls are taken, the watch 
will stop and the time for the test will be registered.

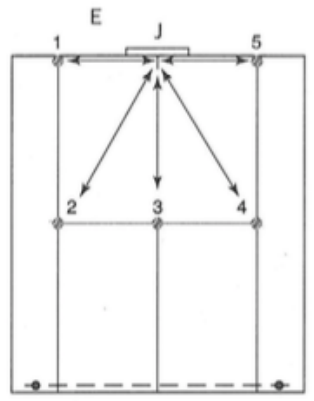

Image 3: Hexagon test (Roetert and Ellenbecker, 2008).

Procedure

For this procedure used for the execution of the tests, the researchers had to go to the clubs. After obtaining the consent of the families and clubs, the players completed the different physical tests voluntarily and anonymously. One researcher was present on-court during the test and no players withdrew. Finally, the statistical analysis of the data was made using an SPSS 21.0. IT package. Descriptive statistics were made after each test and the different variables of the groups were compared by means of Mann-Whitney U tests for independent tests.

\section{RESULTS}

Table 1 shows the descriptive statistics for all participants, for each agility test, $(5 \times 10 \mathrm{~m}$, hexagon and spider test), getting media values between 20 and 30 seconds, in all three tests.

\begin{tabular}{lcccc}
\hline & Minimum & Maximum & M & TD \\
\hline 5xiom test & 18,17 & 33.19 & 23.93 & 3.73 \\
Hexagon test & 14.19 & 40.17 & 20.67 & 8.01 \\
Spider test & 23.67 & 40.83 & 29.18 & 3.28 \\
\hline
\end{tabular}

NB: $M=$ Media; TD = Typical deviation.

Table 1. Descriptive statistics per each agility test

Table 2 shows the relative results of the different agility tests in tennis players depending on their level of playing. As can be noticed, those players with higher playing levels, achieved significantly higher scores in agility tests.

\begin{tabular}{lccccc}
\hline & \multicolumn{2}{c}{ Expert } & \multicolumn{2}{c}{ Beginners } \\
& M & DT & M & DT & Sig. \\
\hline $5 \times 10 m$ test & 21.15 & 2.39 & 24.41 & 3.72 & $.004^{\star *}$ \\
Hexagon test & 17.45 & 3.91 & 21.23 & 8.33 & $.048^{\star}$ \\
Spider test & 26.40 & 1.85 & 29.66 & 3.24 & $.001^{* \star}$ \\
\hline NB: M
\end{tabular}

NB: $M=$ Media; TD = Typical Deviation; ${ }^{\star} p<.05 ;{ }^{\star \star}$ p $<.01$

Table 2. Agility difference between federation and non-federation players.

\section{COMMENTS}

To comply with the first objective, the agility level of tennis players was evaluated. In this aspect, tennis players scored worse in the $5 \times 10$, spider and hexagon tests when compared to the research made by Sánchez, Yagüe, Fernández and Petisco (2014), Le Deuff (2003), and Reid, Quinn and Crespo (2010), respectively, although these studies utilised $12 \mathrm{U}$ athletes.

On the other hand, depending on their playing level, more advanced players scored significantly better in each agility test, this coincides with other tennis research that compared beginner and experienced players. More advanced players displayed a greater level of declarative, procedural and tactical knowledge (García, Moreno, Moreno, Iglesias, \& Del Villar, 2008) apart from a greater accuracy when hitting strokes (Vergauwen, Madou, \& Behets, 2004).

\section{CONCLUSIONS}

Better level players achieved better agility scores in each test. Therefore, the findings from this research can be useful for coaches and trainers for the conditioning, coaching and evaluation of their tennis players.

\section{REFERENCES}

Domínguez, G. (2011). El trabajo de los desplazamientos específicos en tenis. Trances, Revista de transmisión del conocimiento educativo y de la salud, 3(2), 284302.

Galiano, D. (1992). La selección de talentos en el tenis: valoración del rendimiento deportivo. Barcelona: Paidotribo.

García, L. (2006). El conocimiento táctico en tenis. Un estudio con jugadores expertos y noveles. Cuadernos de Psicología del Deporte, 6 (2), 11-20.

García, L.; Moreno, M.P.; Moreno, A.; Iglesias, D., y Del Villar, F. (2008). Análisis de las diferencias en el conocimiento de los jugadores de tenis en función del nivel de pericia deportiva. Motricidad, European Journal of Human Movement, 21, 31-53.

Kovacs, M.S. (2007). Tennis physiology: Training the competitive athlete. Sports Medicine, 37, 111.https://doi.org/10.2165/00007256200737030-00001

Kovacs, M.S. (2009). Movement for tennis: the importance of lateral training. Strength and Conditioning Journal, 31(4),

$77-$ 85.https://doi.org/10.1519/SSC.0b013e3181afe80 6

Jones, P., Bampouras, T., y Marrin, K. (2015). Una investigación sobre los determinantes físicos de la velocidad de cambio de dirección. Revista de Entrenamiento Deportivo, 29(2).

Le Deuff, H. (2003). El entrenamiento físico del jugador de tenis. Barcelona: Paidotribo.

Martínez, E. J. (2008). Pruebas de aptitud física. Barcelona; Paidotribo.

Pieper, S., Exler, T., y Weber, K. (2007). Running speed loads on clay and hard courts in world class tennis. Medicine Science in Tennis, 12(2), 14-17.

Reid, M., Quinn, A., y Crespo, M. (2010). Fuerza y condición física para el tenis. Federación Internacional de Tenis.

Roetert, E.P. y Ellenbecker, T.S. (2008). Preparación física completa para el tenis. Madrid: Tutor.

Roetert,E.P., Ellenbecker, T.S., y Chu.D. (2003). Movement mechanics. In: Reid, M., Quinn, A., Crespo, M. (Eds). Strength and Conditioning for Tennis. London, UK: ITF, pp. 164-173.

Sánchez, J., Yagüe, J.M., Fernández, R.C., y Petisco, C. (2014). Efectos de un entrenamiento con juegos reducidos sobre la técnica y la condición física de jóvenes futbolistas. RICYDE. Revista internacional de ciencias del deporte, 37(10), 221234.https://doi.org/10.5232/ricyde2014.03704

Sánchez-Alcaraz, B.J. (2013). Los desplazamientos y el juego de pies en el tenis. Análisis de las fases y propuestas de aplicación. Actividad Física y Deporte: Ciencia y Profesión, 18, 41-48.

Sánchez-Alcaraz, B.J. (2015). Estructura temporal en la competición de tenis. Coaching and Sport Science Review, 67(23), 17-19. Vergauwen, L.

Madou, B., y Behets, D. (2004). Authentic evaluationof forehand groundstrokes in young low- to intermediate-level tennis players. Medicine and Science in Sports and Exercise, 36(12), 2099-2106. 
RECOMMENDED ITF TENNIS ACADEMY CONTENT (CLICK BELOW)

\section{TTF Academy}

Copyright (c) Bernardino J.Sánchez, Guillermo F. López and Ainara Pagán 2016

(c) (7)
This text is under a Creative Commons BY 4.0 license

You are free to Share - copy and redistribute the material in any medium or format - and Adapt the content - remix, transform, and build upon the material for any purpose, even commercially under the following terms:

Attribution: You must give appropriate credit, provide a link to the license, and indicate if changes were made. You may do so in

any reasonable manner, but not in any way that suggests the licensor endorses you or your use. 